\title{
Effect of Surface Modification on the Absorption and Luminescence Response in tris(8-Hydroxyquinoline) Gallium Films Achieved by Thermal Treatment
}

\author{
Fahmi Fariq Muhammad
}

Soft Materials and Devices Research Laboratory, Department of Physics, Faculty of Science \& Health, Koya University, Koya, Kurdistan Region, Iraq

\begin{abstract}
This work reports on the impact of surface modification on the optical absorption and luminescence response of vacuum deposited tris(8-hydroxyquinoline) gallium (Gaq3) films. This surface modification was achieved by means of thermal treatment under nitrogen gas in the temperature range from $85^{\circ} \mathrm{C}$ to $255^{\circ} \mathrm{C}$. The results of field emission scanning electron microscopy (FESEM) and x-ray diffraction (XRD) technique ascertained the formation of amorphous nano-rods along the surface of Gaq3 films. Considerable improvement in the absorption and luminescence characteristics of Gaq3 films was observed upon surface modification, which has been resulted from this treatment process.
\end{abstract}

Received on 31-05-2015 Accepted on 11-08-2015 Published on 14-09-2015

Keywords: Gaq3, thermal treatment, FESEM, XRD morphology.

\section{INTRODUCTION}

Tris(8-hydroxyquinoline) gallium (Gaq3) is a well-known organometallic material widely used in the development of organic electronics devices such as organic light emitting diodes (OLEDs) and organic solar cells (OSCs) [1-4]. It was reported that the utilization of Gaq3 in OLEDs has improved the device performance in comparison to that of the tris(8hydroxyquinoline) aluminium (Alq3) based ones [5]. Investigations on the Gaq3 properties received considerable attention at both theoretical and practical levels [6-9]. Improvement in the Gaq3 properties is crucial for its application in OLED and/or OSC devices. Various strategies were undertaken by researchers to enhance the physical behaviour of organic materials, namely thermal annealing process [10-12], in-situ controlled substrate temperature [13] and the use of different substrates [14]. Thermal evaporation under cold trap at different working temperatures and pressures was examined to fabricate crystalline Alq3 and Gaq3 nanostructures on silicon substrates [13, 15]. It was found that this has led to enhance the photoluminescence action in the films, but the crystallized structure may produce undesired light scattering or leak current in OLED application $[16,17]$. This research work is conducted to apply the postthermal annealing process under nitrogen gas to modify the

"Soft Materials and Devices Research Laboratory, Department of Physics, Faculty of Science \& Health, Koya University, Koya, Kurdistan Region, Iraq; Tel: +96 4750 1168841; E-mail: fahmi.fariq@koyauniversity.org, fahmi982@gmail.com

E-ISSN: 2369-3355/15 @ 2015 Lifescience Global surface morphology of vacuum deposited Gaq3 film. The impact of this surface modification was then investigated and analysed. It was found that this process is a viable tool to fabricate amorphous Gaq3 nanostructures along the surface of the films and can be a novel route to modify the absorption and luminescence behaviours of Gaq3 films. To the author's knowledge this is the first work emphasizes the modification of surface distribution of Gaq3 films by thermal treatment under nitrogen gas, by which production of nano-rods was achieved.

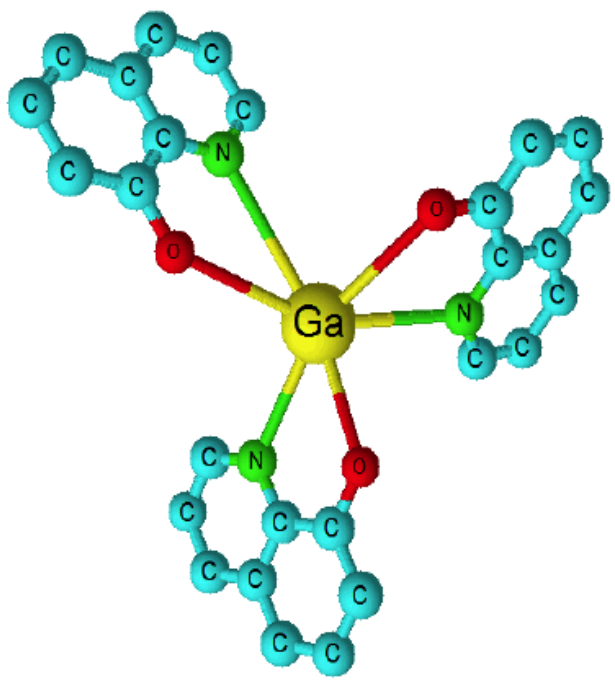

Figure 1: Three dimensional view of Gaq3 structure. 


\section{MATERIALS AND METHODS}

Tris (8-hydroxyquinolinate) gallium (Gaq3) was purchased from Sigma-Aldrichin powder form and used as received. Figure 1 shows the chemical structure of Gaq3. Films of Gaq3 were thermally evaporated onto pre-cleaned quartz substrates by utilizing a home-made thermal evaporator under a pressure of about $10^{-4} \mathrm{mbar}$. The quartz slides were cleaned ultrasonically with Deacon ${ }^{\circledR}$ Neutracon foam solution for 15 minutes followed by rinsing in acetone, ethanol and distilled water for 10 minute in ultrasonic bath, respectively. Finally, the quartz slides were dried thoroughly by blowing the nitrogen gas.

Gaq3 films with thickness $\sim 764 \mathrm{~nm}$ were post-thermally annealed under flowing nitrogen gas in a barrel furnace. The process was set for 10 minute at temperatures of $85{ }^{\circ} \mathrm{C}, 160{ }^{\circ} \mathrm{C}, 235{ }^{\circ} \mathrm{C}$ and $255^{\circ} \mathrm{C}$. Field emission scanning electronic microscopy technique (FESEM, Quanta 200F) was used to capture the surface morphology of the films. X-ray
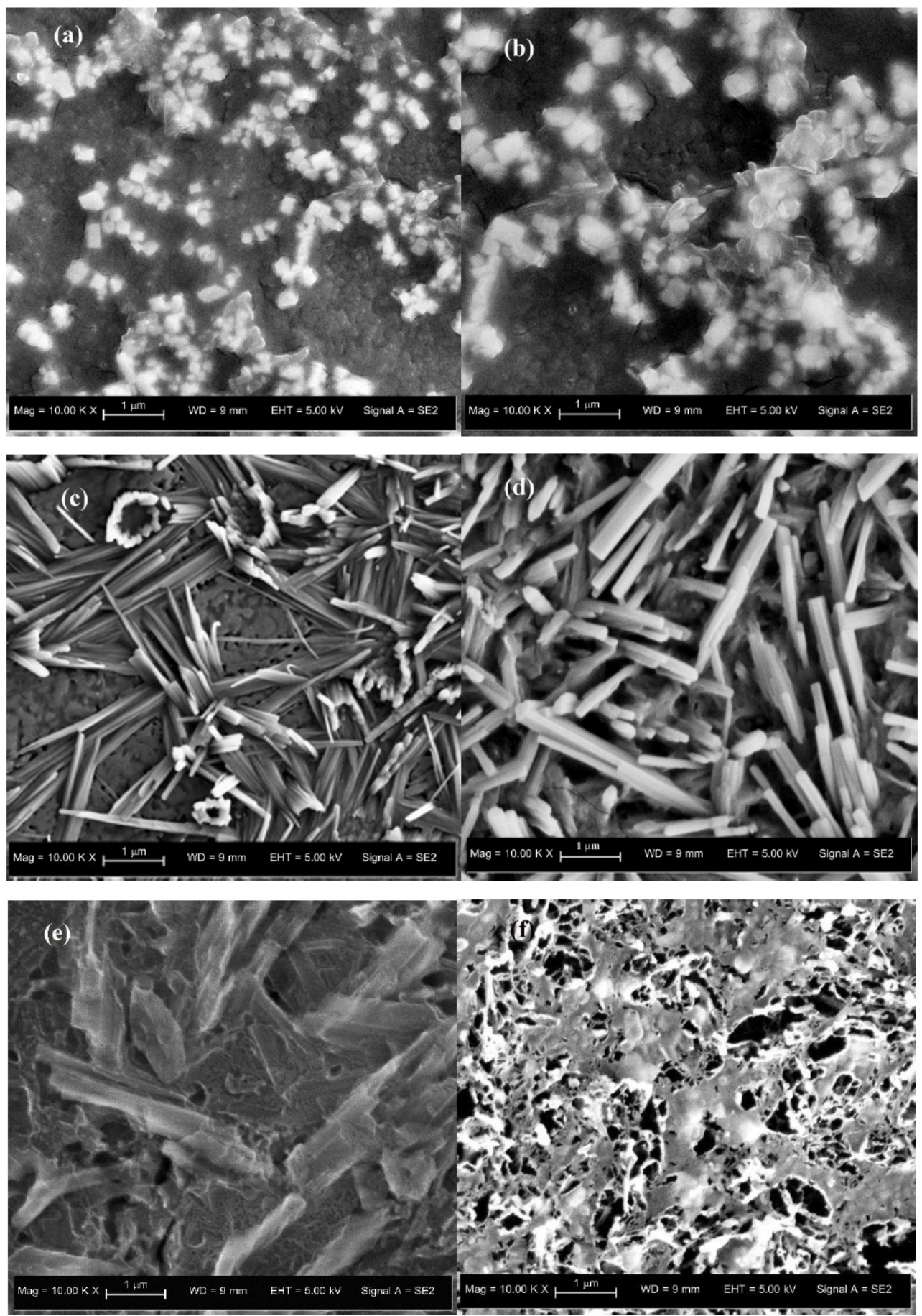

Figure 2: FESEM images of untreated Gaq3 films (a) and post-thermally treated ones at $85{ }^{\circ} \mathrm{C} \mathrm{(b),} 160{ }^{\circ} \mathrm{C}(\mathbf{c}), 235{ }^{\circ} \mathrm{C}(\mathbf{d}), 255^{\circ} \mathrm{C}(\mathbf{e})$ and $310^{\circ} \mathrm{C}$ (f) under nitrogen gas 
diffraction technique (a Bruker $\mathrm{AXS}$ ) with $\mathrm{Cu} \mathrm{K}_{\alpha}$ radiation of wavelength $\lambda=1.5406 \mathrm{~A}^{\circ}$ as a source was utilized to measure the XRD patterns for the films. The absorbance of the films was recorded at room temperature using Jasco $\mathrm{V}$ 570 UV-Vis-NIR spectrophotometer in the wavelength range from 200 to $2500 \mathrm{~nm}$, while photoluminescence spectra for the films were carried out at room temperature using a LS50B PERKIN ELMER luminescence spectrometer in the wavelength range from $200 \mathrm{~nm}$ to $800 \mathrm{~nm}$.

\section{RESULTS AND DISCUSSION}

Figure 2 shows the FESEM images of untreated and postthermally treated Gaq3 films under nitrogen gas. Noticeably, the surface morphology of the films has not been pronouncedly affected by temperatures under $160{ }^{\circ} \mathrm{C}$, while temperatures of 160 and $235{ }^{\circ} \mathrm{C}$ were highly effective to produce clear modification in the molecular distribution of the films, thereby growing nanostructured rods. The growth of nanostructure along the surface of Gaq3 at prescribed temperatures can be understood by means of molecular migration, in which the Gaq3 molecules migrate and pile up by acquiring enough thermal energy from the appropriate heating treatment [14]. It is worth mentioning that annealing process beyond $255{ }^{\circ} \mathrm{C}$ has made the rods to be degraded and cross linked. This is where the formation of crystalline portion in the films was ascertained as shown in Figure 3. The hard heating temperature of $310^{\circ} \mathrm{C}$ produced dark spots along the surface of the films indicating the presence of high portion for Gaq3 to be melted and sublimate ultimately.

Figure 3 shows the XRD results recorded for post-thermally treated films at 235 and $255{ }^{\circ} \mathrm{C}$, by which the fortified and degraded nanostructures were formed, respectively. The broad absorption band in between 15 to 30 degrees is referred to that of the quartz substrates. Nevertheless, crystalline region was seen to appear for the films annealed at $255{ }^{\circ} \mathrm{C}$. The intense diffraction peak at $2 \theta=15.9^{\circ}$ confirming the crystallinity was estimated to correspond with a periodicity of $d=0.557 \mathrm{~nm}$.

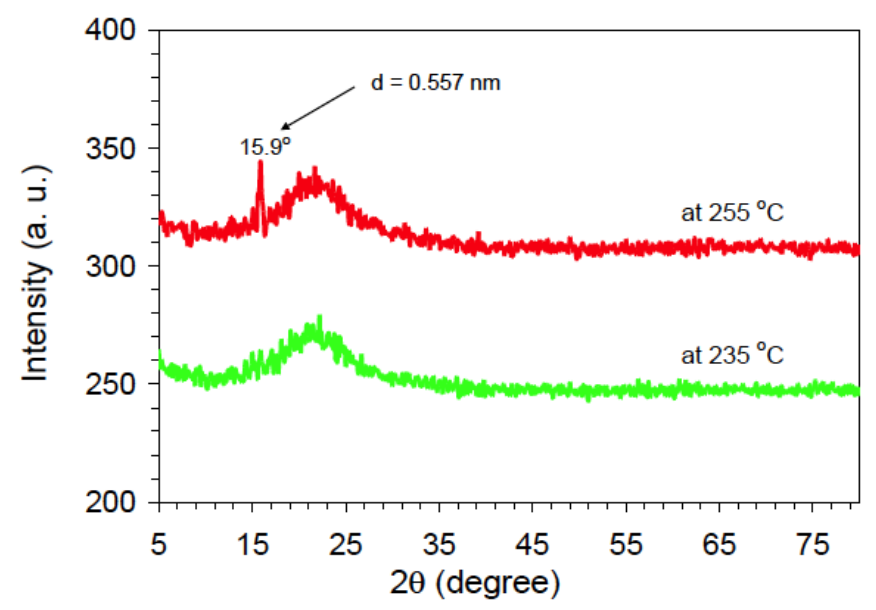

Figure 3: The XRD patterns for the Gaq3 films annealed at 235 and $255^{\circ} \mathrm{C}$.
The absorption coefficient $(\alpha)$ for the films was determined by using the relation $\alpha=2.303 A / t$ [18], where $A$ is the absorbance of the film and $t$ its thickness. Figure 4 shows the absorption coefficient of the pristine and annealed films in the temperature range from $85{ }^{\circ} \mathrm{C}$ to $255{ }^{\circ} \mathrm{C}$ under nitrogen gas for 10 minute. Two main peaks were found for the untreated film; the first peak is at photon energy of about $3.14 \mathrm{eV}$, while the second one is located in the ultraviolet region with relatively broad and intense at about $4.67 \mathrm{eV}$. These peaks were assigned to the existence of electronic transitions from $\pi \rightarrow \pi^{*}$ and $4 p \rightarrow \pi^{*}$ orbital energy bands, respectively [9]. One can observe that increased annealing temperature has made the intensity of visible band to be lowered in opposite trend to that of the ultraviolet band. Nevertheless, at temperature of $235{ }^{\circ} \mathrm{C}$, the absorption spectrum has become broader covering the whole UV range and part of the visible region. The decrease in the UV peak was also found for Alq3 films [19] and it was attributed to the change in chemical nature of Alq3 film due to its exposure to atmosphere [20]. In this work, Gaq3 films were annealed under nitrogen gas. So the impact of atmospheric exposure can be ignored. Alternatively, nanostructure formation resulted from morphological variation can be responsible for this great modification in optical absorption. This can be elaborated as within the broad distribution of molecular packings, favourable $\pi-\pi$ overlaps between facing ligands may occur [21], thereby involving interaction and energy exchanges at molecular level which have consequences on the spectral properties of the molecules [22].

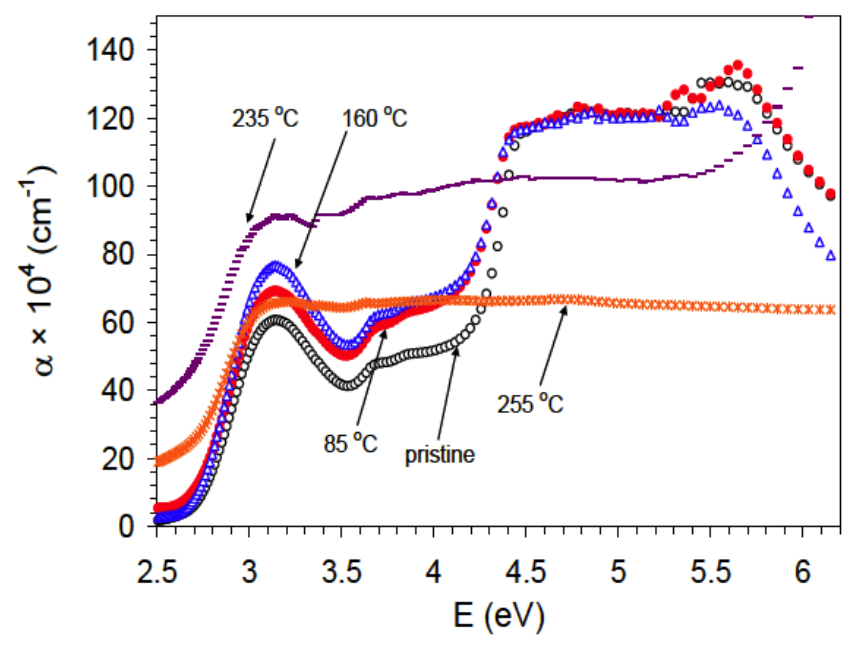

Figure 4: Absorption coefficient for untreated and post-thermally treated films of Gaq3 under nitrogen gas.

Figure 5 shows the change in the energy gap of Gaq3 film at different temperatures. The energy gap was estimated by extrapolating the linear part of absorption coefficient in Figure 4 at low energy. One can notice that the energy gap is decreased with the increase of temperature, suggesting the enhancement of molecular packing. Noticeably, the greatest impact of heat treatment on the energy gap was found to be at $235{ }^{\circ} \mathrm{C}$, thereby producing a broad absorption spectrum, 
as it was shown in Figure 4. Nevertheless, beyond $235^{\circ} \mathrm{C}$ the energy gap was seen to be increased due to hard heating,

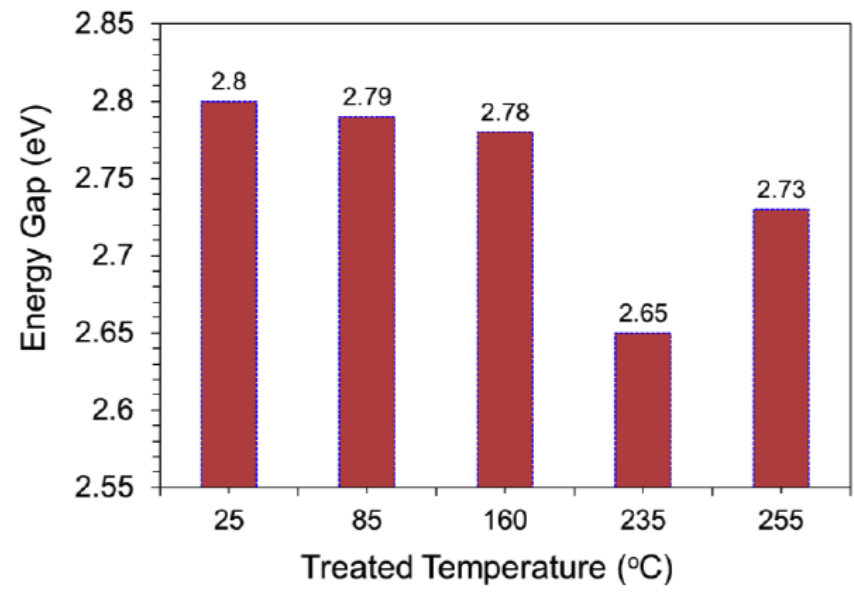

Figure 5: Energy gap alteration for untreated and post-thermally treated films of Gaq3 under nitrogen gas.

Figure 6 shows the luminescence response of untreated and treated Gaq3 films at excitation wavelength of $396 \mathrm{~nm}$. The peak of luminescence intensity for untreated films was located at $535 \mathrm{~nm}$, which is close to that reported in literature [5]. Noteworthy, luminescence intensity was seen to be increased by increasing the treatment temperature. It was increased to nearly five times stronger than that of untreated films at $235{ }^{\circ} \mathrm{C}$. However, at $255{ }^{\circ} \mathrm{C}$ the luminescence intensity was quenched due to the crystalline region formation [20] (see Figure 3). It was reported that the luminescence behaviour is strongly related to the nature and structure of films [15, 23]. Consequently, the variation in luminescence can be attributed to the morphological modifications which have been brought about the thermal treatment process under nitrogen gas.

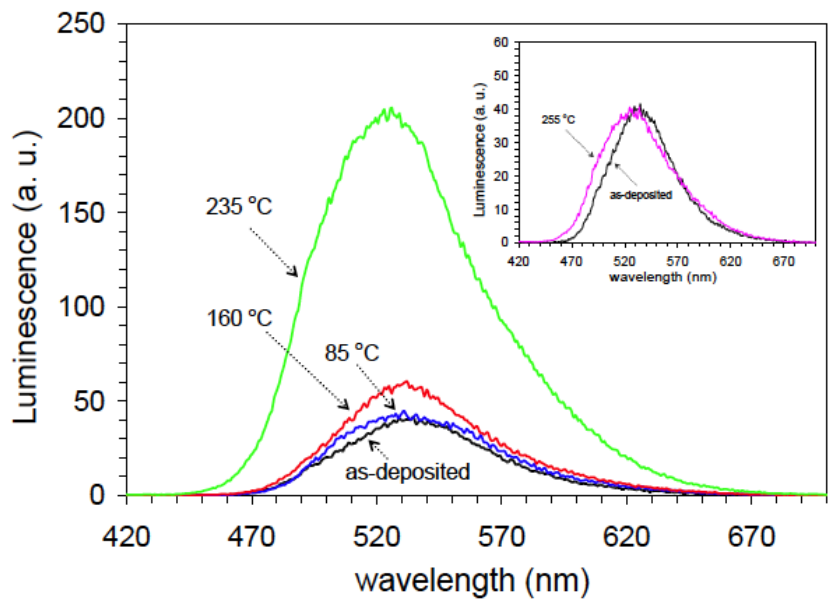

Figure 6: Luminescence spectra for untreated and post-thermally treated films of Gaq3 under nitrogen gas.

\section{CONCLUSIONS}

Modification in surface morphology of Gaq3 films was achieved by means of thermal treatment under nitrogen gas in the temperature range from $85{ }^{\circ} \mathrm{C}$ to $255{ }^{\circ} \mathrm{C}$. This modification process was seen to be effective in determining the optical absorption and luminescence response of Gaq3 films. The formation of amorphous nano-rods was confirmed through FESEM and XRD investigations. A broad absorption spectrum and intense luminescence to five times stronger than that of untreated films was noticed at treated temperature of $235{ }^{\circ} \mathrm{C}$. The quenched luminescence response at higher treatment temperatures was attributed to the formation of crystalline region in the Gaq3 films. Gaq3 can be a promising material for the OLED and OSC application upon controlling its surface morphology.

\section{ACKNOWLEDGEMENT}

The author would like to thank the Department of Physics, Koya University, for the administrative support to this work.

\section{REFERENCES}

[1] Kao P-C, Chu S-Y, Huang H-H, Tseng Z-L, Chen Y-C. Improved efficiency of organic photovoltaic cells using tris (8-hydroxy-quinoline) aluminum as a doping material. Thin Solid Films 2009; 517: 5301-4. http://dx.doi.org/10.1016/..tsf.2009.03.147

[2] Vivo P, Jukola J, Ojala M, Chukharev V, Lemmetyinen H. Influence of Alq3/Au cathode on stability and efficiency of a layered organic solar cell in air. Solar Energy Materials and Solar Cells 2008; 92: 1416-20. http://dx.doi.org/10.1016/i.solmat.2008.06.002

[3] Muhammad FF. Design approaches to improve organic solar cells. Journal of Technology Innovations in Renewable Energy 2014; 3: 1-8. http://dx.doi.org/10.6000/1929-6002.2014.03.02.4

[4] Mohd Sarjidan MA, Basri SH, Za'Aba NK, Zaini MS, Abd Majid WH. Electroluminescence and negative differential resistance studies of TPD:PBD:Alq3 blend organic-light-emitting diodes. Bull Mater Sci 2015; 38: 235-9.

http://dx.doi.org/10.1007/s12034-014-0807-6

[5] Wang L, Jiang X, Zhang Z, Xu S. Organic thin film electroluminescent devices using Gaq3 as emitting layers. Displays 2000; 21: 47-9. http://dx.doi.org/10.1016/S0141-9382(00)00035-4

[6] Gahungu G, Zhang J. Molecular geometry, electronic structure and optical properties study of meridianal tris(8-hydroxyquinolinato) gallium(III) with ab initio and DFT methods. Journal of Molecular Structure: THEOCHEM 2005; 755: 19-30.

http://dx.doi.org/10.1016/..theochem.2005.06.017

[7] Zhang J, Frenking G. Quantum chemical analysis of the chemical bonds in $\mathrm{Mq} 3\left(\mathrm{M}=\mathrm{Al}^{\mathrm{III}}, \mathrm{Ga}^{\mathrm{III}}\right)$ as emitting material for OLED. Chem Phys Lett 2004; 394: 120-5. http://dx.doi.org/10.1016/j.cplett.2004.06.074

[8] Hernández I, Gillin WP. Influence of high hydrostatic pressure on Alq3, Gaq3, and Inq3 (q = 8-hydroxyquinoline). J Phys Chem B 2009; 113: $14079-86$.

http://dx.doi.org/10.1021/ip905108x

[9] Muhammad FF, Abdul Hapip Al, Sulaiman K. Study of optoelectronic energy bands and molecular energy levels of tris (8hydroxyquinolinate) gallium and aluminum organometallic materials from their spectroscopic and electrochemical analysis. J Organometallic Chem 2010; 695: 2526-31. http://dx.doi.org/10.1016/i.jorganchem.2010.07.026

[10] Singh R, Kumar J, Singh RK, Kaur A, Sood KN, Rastogi RC. Effect of thermal annealing on surface morphology and physical properties of poly(3-octylthiophene) films. Polymer 2005; 46: 9126-32.

http://dx.doi.org/10.1016/.jpolymer.2005.07.032

[11] Satapathy S, Pawar S, Gupta PK, Varma KBR. Effect of annealing on phase transition in poly(vinylidene fluoride) films prepared using polar solvent. Bull Mater Sci 2011; 34: 727-33. http://dx.doi.org/10.1007/s12034-011-0187-0

[12] Somashekar R, Gopalkrishna Urs R. Effect of annealing on crystal size in pure Mysore silk fibres. Bull Mater Sci 1991; 14: 87-91. http://dx.doi.org/10.1007/BF02745093

[13] Cho C-P, Yu C-Y, Perng T-P. Growth of AIQ3 nanowires directly from amorphous thin film and nanoparticles. Nanotechnology 2006; 17: 
5506-10.

http://dx.doi.org/10.1088/0957-4484/17/21/035

[14] Kumar P, Sonia, Patel RK, Prakash C, Goel TC. Effect of substrates on phase formation in PMN-PT 68/32 thin films by sol-gel process. Mater Chem Phys 2008: 110: 7-10.

http://dx.doi.org/10.1016/j.matchemphys.2007.11.035

[15] Yu Y-W, Cho C-P, Perng T-P. Crystalline Gaq3 nanostructures: preparation, thermal property and spectroscopy characterization. Nanoscale Res Lett 2009; 4: 820-7. http://dx.doi.org/10.1007/s11671-009-9321-v

[16] Higginson KA, Zhang X-M, Papadimitrakopoulos F. Thermal and morphological effects on the hydrolytic stability of aluminum tris(8hydroxyquinoline) (Alq3). Chem Mater 1998; 10: 1017-20. http://dx.doi.org/10.1021/cm970599a

[17] Yokoyama D, Sakaguchi A, Suzuki M, Adachi C. Horizontal orientation of linear-shaped organic molecules having bulky substituents in neat and doped vacuum-deposited amorphous films. Organic Electronics 2009; 10: 127-37. http://dx.doi.org/10.1016/j.orgel.2008.10.010

[18] Muhammad FF, Sulaiman K. Utilizing a simple and reliable method to investigate the optical functions of small molecular organic films - Alq3 and Gaq3 as examples. Measurement 2011; 44: 1468-74. http://dx.doi.org/10.1016/i.measurement.2011.05.017
Djurišić AB, Lau TW, Lam LSM, Chan WK. Influence of atmospheric exposure of tris (8-hydroxyquinoline) aluminum (Alq3): a photoluminescence and absorption study. Appl Phys A: Mater Sci Process 2004; 78: 375-80. http://dx.doi.org/10.1007/s00339-002-1915-5

[20] Credo GM, Winn DL, Buratto SK. Near-field scanning optical microscopy of temperature- and thickness-dependent morphology and fluorescence in Alq3 films. Chem Mater 2001; 13: 1258-65. http://dx.doi.org/10.1021/cm000672o

[21] Brinkmann M, Gadret G, Muccini M, Taliani C, Masciocchi N, Sironi A Correlation between molecular packing and optical properties in different crystalline polymorphs and amorphous thin films of merTris(8-hydroxyquinoline)aluminum(III). J Am Chem Soc 2000; 122 5147-57.

http://dx.doi.org/10.1021/ja993608k

[22] Auzel F, Baldacchini G, Baldacchini T, Chiacchiaretta P, Balaji Pode R. Rayleigh scattering and luminescence blue shift in tris(8hydroxyquinoline) aluminum films. J Luminescence 2006; 119-120: 111-5.

http://dx.doi.org/10.1016/j.jlumin.2005.12.018

[23] Hernández I, Gillin WP, Somerton M. Spectroscopic study of Mq3 ( $\mathrm{M}=\mathrm{Al}, \mathrm{Ga}, \quad$ In, $\mathrm{q}=8$-hydroxyquinolinate) at high pressure. Luminescence 2009; 129: 1835-9.

http://dx.doi.org/10.1016/j.jlumin.2009.02.030 